\section{Aisha A Qasim}

BDS, MSc (Assist Lect)

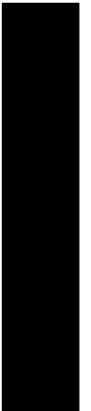

Oral health status among secondary school students in Mosul City Centre/Iraq

\author{
Dept of Pedod, orthod, and Prev Dentistry \\ College of Dentistry, University of Mosul
}

\begin{abstract}
Aims: To evaluate the oral hygiene and gingival health among secondary school students and to find if there was any variation between age and sex groups in Mosul City Centre. Material and Methods: A sample of 630 students aged 16-18 years old (278 males, 352 females) were examined using plaque index score and gingival index. The clinical examinations were carried out in the school using plane mouth mirrors, WHO periodontal probes to detect the dental plaque and gingival health. Results: Showed that the mean plaque score for the total sample was 0.96 , the plaque index increased with age. Females reported less mean plaque scores than males with statistically significant difference between them. The mean gingival score was 0.56 for the total sample and it increased with age. There was a significant difference between males and females. The study revealed that $35.9 \%$ of the total sample did not brush their teeth. Therefore the objective of dental health education to those subjects is to brush their teeth regularly and to improve the effectiveness of oral hygiene practice. Conclusion: Periodontal disease is indirectly related to the exposure of bacterial plaque for long time which calls for coordinated planning of preventive strategies and urgent priorities.

Key Words: Oral cleanliness, plaque index, gingival index, secondary school students.
\end{abstract}

Qasim AA. Oral health status among secondary school students in Mosul City Centre/Iraq. Al-Rafidain Dent J. 2007; 7(2): 180-185.

Received: 2/7/2006 Sent to Referees: 3/7/2006

Accepted for Publication: 31/7/2006

\section{INTRODUCTION}

Periodontal disease is a generalized term for a range of the pathological condition affecting the supporting and investing structure of the teeth ${ }^{(1)}$, which caused by dental plaque, which reforms constantly after cleaning and is affected by diet. Bacterial plaque produces a number of substances which may penetrate the gingiva and causes inflammation. ${ }^{(2)}$ Most children have gingivitis of varying severity, while periodontitis affected a sizeable minority of teenagers and most adults so it is important to prevent the onset of the disease or at least to slow its rate of progression in order that more people can retain their natural dentitions. ${ }^{(3,4)}$

The hormonal changes associated with puberty may be responsible for the peak ${ }^{(5)}$, which is recognized in this age group, the temporary decline in prevalence and severity after puberty may reflect an increase in social awareness and resulting improved oral hygiene. So the most effective means of promoting oral health are these health care practices performed by people themselves with tooth brushing being sited as "the most appropriate and hygiene habit". $(6,7)$

Preventive strategies, treatment of periodontal disease, and supportive care regimens may all be supplemented in certain circumstances by chemical methods of plaque control although chemical antiplaque agents not be regarded as a convenient replacement for the more traditional mechanical means of eliminating dental plaque. ${ }^{(8)}$

The aims of the study were to evaluate the oral hygiene and gingival health among secondary school students and to find if there was any variation between age and sex groups in Mosul City Centre.

\section{MATERIAL AND METHODS}

The samples of the study were composed of 630 secondary school students (278 males, 352 females) selected randomly from four secondary schools (2 for boys, 2 for girls) in Mosul City Center. The samples were divided into 3 age groups namely 16, 17 and 18 years old, which 
represent the first, second and the last year of secondary schooling.

Each student was asked about frequency of tooth brushing by direct contact whether infrequent, once, twice or more. Each student was sit in upright position in front of the examiner.

The clinical examinations were carried out in the schools using adequate day light, plane mouth mirrors, WHO periodontal probes to detect the dental plaque and gingival health. ${ }^{(9)}$

The indices used for assessment of gingival and periodontal condition were as follow:

1- Plaque index by Silness and Le ${ }^{(10)}$ to evaluate the oral hygiene of the students are:

Score 0: No plaque in gingival area.

Score 1: A film of plaque adherent to the gingival margin and the adjacent area of the tooth. The plaque may only be recognized by running a probe across the tooth surface.

Score 2: A moderate accumulation of soft deposit within the gingival pocket on the tooth and gingival margin. This can be recognized with the naked eye.

Score 3: A heavy accumulation of plaque within gingival pocket or on the tooth and gingival margin.

2- Gingival index by Le and Silness ${ }^{(11)}$ to evaluate the gingival health of the studentts.

Score 0: Normal gingiva.

Score 1: Mild inflammation: This includes slight change in colour, slight oedema, no bleeding on probing .

Score 2: Moderate inflammation: Redness, oedema, bleeding of the gum on probing.

Score 3: Severe inflammation: Marked redness, oedema ulceration and there is a tendency for spontaneous bleeding.

The statistical analysis of the data included the mean and standard error for plaque and gingival indices using one way analysis of variance (ANOVA) and Duncan's Multiple Range Test. Comparing between total males and females was done using F-ratio test. Differences were tested for their significancy for plaque index and gingival index at $p \leq 0.0001$ level.

\section{RESULTS}

There were 630 secondary school students comprising $44.1 \%$ males and $55.9 \%$ females. The population samples were divided into three age groups (Table 1).

Table (1): Number and percentage of individuals distributed according to sex and age groups

\begin{tabular}{ccccccc}
\hline \multirow{2}{*}{ Age Group (years) } & \multicolumn{2}{c}{ Male } & \multicolumn{2}{c}{ Female } & \multicolumn{2}{c}{ Total } \\
\cline { 2 - 7 } & No. & $\mathbf{\%}$ & No. & $\mathbf{\%}$ & No. & $\mathbf{\%}$ \\
\hline $\mathbf{1 6}$ & 86 & 30.94 & 175 & 49.72 & 261 & 41.43 \\
$\mathbf{1 7}$ & 96 & 34.53 & 87 & 24.72 & 183 & 29.05 \\
$\mathbf{1 8}$ & 96 & 34.53 & 90 & 25.56 & 186 & 29.52 \\
Total & 278 & 100 & 352 & 100 & 630 & 100 \\
\hline
\end{tabular}

No: Numbers of samples

Table (2) showed the number and percentage of students according to the frequency of tooth brushing. The study indicated that about $35.9 \%$ of the sample did not brush their teeth. The females reported less frequently brush their teeth $(35.8 \%)$ than males $(45.2 \%)$ once or twice and more daily. Also the older age groups (17 and 18 years) in males reported more frequently brushed their teeth than younger age groups (16 years old) while in females the frequency of tooth brushing increased for students who brushes their teeth infrequently.

Table (3 and 4) showed the plaque index scores according to sex and age groups. The mean plaque for the total sample was 0.97 and males reported higher mean than females in all age groups and the total males also higher than total females with statistical significant difference at $p \leq 0.0001$. 
The study showed that the mean plaque increased with age with significant diff- erence between 16 and 17, 16 and 18 years old.

Table (2): Frequency and percentage distribution of individuals according to tooth brushing by sex and age groups

\begin{tabular}{|c|c|c|c|c|c|c|c|c|c|}
\hline \multirow{3}{*}{ Sex } & \multirow{3}{*}{ Frequency of tooth brushing } & \multicolumn{8}{|c|}{ Age Group (years) } \\
\hline & & \multicolumn{2}{|c|}{16} & \multicolumn{2}{|c|}{17} & \multicolumn{2}{|c|}{18} & \multicolumn{2}{|c|}{ Total } \\
\hline & & No. & $\%$ & No. & $\%$ & No. & $\%$ & No. & $\%$ \\
\hline \multirow{4}{*}{ Male } & Never & 45 & 52.3 & 40 & 41.6 & 40 & 41.6 & 125 & 45.0 \\
\hline & Infrequent & 23 & 26.7 & 30 & 31.3 & 30 & 31.3 & 83 & 29.9 \\
\hline & Once & 15 & 17.5 & 24 & 25.0 & 24 & 25.0 & 63 & 22.7 \\
\hline & Twice or more & 3 & 3.5 & 2 & 2.1 & 2 & 2.1 & 7 & 22.5 \\
\hline \multirow{4}{*}{ Female } & Never & 69 & 39.4 & 15 & 17.2 & 17 & 18.9 & 101 & 28.7 \\
\hline & Infrequent & 47 & 26.9 & 31 & 35.6 & 47 & 52.2 & 125 & 35.5 \\
\hline & Once & 27 & 15.4 & 20 & 23.1 & 17 & 18.9 & 64 & 18.2 \\
\hline & Twice or more & 32 & 18.3 & 21 & 24.1 & 9 & 10.0 & 62 & 17.6 \\
\hline \multirow{4}{*}{ Total } & Never & 114 & 43.7 & 55 & 30.1 & 57 & 30.7 & 226 & 35.9 \\
\hline & Infrequent & 70 & 26.8 & 61 & 33.3 & 77 & 41.4 & 208 & 33.0 \\
\hline & Once & 42 & 16.1 & 44 & 24.0 & 41 & 22.0 & 127 & 20.2 \\
\hline & Twice or more & 35 & 13.4 & 23 & 12.6 & 11 & 5.9 & 69 & 10.9 \\
\hline
\end{tabular}

Table (3): Analysis of Variance of plaque index (PI) according to sex and age groups

\begin{tabular}{cccccc}
\hline Source & df & Sum of square & Mean square & F-value & $\boldsymbol{P}$-value \\
\hline Between groups & 2 & 5.534 & 2.767 & & \\
Within groups & 349 & 42.526 & 122 & 22.706 & .000 \\
Total & 351 & 48.059 & & & \\
\hline
\end{tabular}

df: degree of freedom.

Table (4)Duncan Multiple Range Test of plaque index (PI) according to sex and age groups

\begin{tabular}{cccc}
\hline \multirow{2}{*}{ Age groups (years) } & \multicolumn{3}{c}{ Mean \pm SE } \\
\cline { 2 - 4 } & Male & Female & Total \\
\hline $\mathbf{1 6}$ & $1.03 \pm 0.04 \mathrm{a}$ & $0.94 \pm 0.028 \mathrm{~b}$ & $0.97 \pm 0.024 \mathrm{~b}$ \\
$\mathbf{1 7}$ & $1.04 \pm 0.04 \mathrm{a}$ & $0.67 \pm 0.04 \mathrm{a}$ & $0.86 \pm 0.03 \mathrm{a}$ \\
$\mathbf{1 8}$ & $1.04 \pm 0.04 \mathrm{a}$ & $1.0 \pm 0.03 \mathrm{~b}$ & $1.02 \pm 0.02 \mathrm{~b}$ \\
Total & $1.04 \pm 0.36^{*}$ & $0.89 \pm 0.02^{*}$ & $0.96 \pm 0.02$ \\
\hline Means with the same letters are statistically not significant at $(p>0.05)$
\end{tabular}


Table (5 and 6) showed the mean gingival score index according to sex and age groups. The mean for the total sample was
0.54 . Males reported higher mean gingival score than females; this difference was found to be significant at $p \leq 0.0001$.

Table (5): Analysis of Variance and Duncan Multiple Range Test of gingival index according to sex and age groups

\begin{tabular}{cccccc}
\hline Source & df & Sum of square & Mean square & F-value & $P$-value \\
\hline Between groups & 2 & 1.975 & 0.987 & & \\
Within groups & 349 & 43.429 & 124 & 7.935 & .000 \\
$\quad$ Total & 351 & 45.404 & & & \\
\hline
\end{tabular}

df: degree of freedom.

Table (6): Duncan Multiple Range Test of gingival index according to sex and age groups

\begin{tabular}{cccc}
\hline \multirow{2}{*}{ Age groups (years) } & \multicolumn{3}{c}{ Mean \pm SE } \\
\cline { 2 - 4 } & Male & Female & Total \\
\hline $\mathbf{1 6}$ & $0.60 \pm 0.03 \mathrm{a}$ & $0.52 \pm 0.03 \mathrm{a}$ & $0.54 \pm 0.02 \mathrm{a}$ \\
$\mathbf{1 7}$ & $0.61 \pm 0.03 \mathrm{a}$ & $0.44 \pm 0.04 \mathrm{a}$ & $0.53 \pm 0.03 \mathrm{a}$ \\
$\mathbf{1 8}$ & $0.61 \pm 0.03 \mathrm{a}$ & $0.64 \pm 0.04 \mathrm{~b}$ & $0.63 \pm 0.03 \mathrm{~b}$ \\
Total & $0.60 \pm 0.02^{*}$ & $0.53 \pm 0.02^{*}$ & $0.56 \pm 0.01$ \\
\hline
\end{tabular}

Means with the same letters are statistically not significant at $(p>0.05)$

\section{DISCUSSION}

Tooth brushing data indicated that about $35.9 \%$ of the sample did not bush their teeth. The percentage of subjects brushed their teeth is less than other studies carried out in developed countries ${ }^{(12-16)}$ and it was higher than studies carried out in Iraq ${ }^{(17-21)}$ but less than other study carried out in Ir$\mathrm{aq}^{(22)}(50 \%)$ and in Yemen ${ }^{(23)}(45.1 \%)$. These differences could be attributed to differences in person's habitual behavior, dental health education, occupation and income level.

In this study females reported less frequently brush their teeth $(35.8 \%)$ than males $(45.2 \%)$ especially in younger age groups. This is not in accordance with many studies carried out in developing and developed countries. ${ }^{(14-26)}$ The mean plaque score for the total sample was 0.94. There was a significant difference between 16 and 17, 17 and 18 years old but not all age groups. This may be attributed to the fact that the amount of plaque is influenceed by person's oral hygiene and by various plaque retention factors. This is not in accordance with many studies carried out in developed and developing countries. ${ }^{(27-30)}$

Females reported less mean plaque score than males with statistical significant difference between them because the frequency with which teeth are brush does not necessarily imply effective plaque remov- al. This is in accordance with many studies in developed and developing countries. ${ }^{(27-}$ 31) The mean gingival score was 0.56 for the total sample and it increased with age because tooth brushing is associated with grouping and personal hygiene or due to other causes like hormonal changes due to puberty, or due to less attitude to visit dental clinic and even for those brushes their teeth, they brush in incorrect way, as a high plaque was reported. This is in accordance with many studies ${ }^{(5,21,32,33)}$. This study showed that the gingival health in females was better than males with statistical significant difference because females brush their teeth more effectively than males because they care much about their looking; i.e., gingival health was worse in males. This confirms the finding of other studies carried out in the developing and developed countries. ${ }^{(34-40)}$

\section{CONCLUSION}

Gingival and periodontal diseases are indirectly caused by accumulation of plaque biofilm for long time which calls for integrated and coordinated planning of preventive programs especially for developing countries.

\section{REFERENCES}

1- Schenkein H. The pathogenesis of periodontal disease. J Periodontol. 1999; 70: 
457-470.

2- Leatherman GH. Oral hygiene for children: A look at what we must have and what we should do. Int Dent J. 1982; 32 (3): 252-258.

3- Matsson L, Goldberg P. Gingival inflammatory reaction in children at different ages. J Clin Periodontol. 1995; 22: 98101.

4- Khamrco TY. Assessment of periodontal disease using the CPITN index in a rural population in Ninevah, Iraq. East Meditter Health J. 1999; 5 (3): 439-555.

5- Jenkins WMM, Papanou PN. Epidemiology of periodontal disease in children and adolescents. Periodontol. 2001; 26: 16-32.

6- Honkala. Oral health promotion with children and adolescents In: Lshou Ed, Blinkhorn As. Oral Health Promotion. Oxford: Oxford university press, UK, 1993. Pp: 169-187

7- Khamrco Ty, Gasgoos SS. The effectiveness of different methods of teaching dental health on the incidence of plaque and gingivitis. Al- Rafidain Dent $J$. 2002; 2 (spiss): 388-398.

8- Murray CBE, Hunn JH, Steele JG. The Prevention of Oral Disease, $4^{\text {th }}$ ed. Oxford University Press Inc. New York 2003; Pp: 125-144.

9- World Health Organization. Epidemiology. Etiology and the Prevention of Periodontal Disease. WHO Technical Report Series No. 621, World Health Organization, Geneva, Switzerland, 1978.

10- Silness J, Le H. Periodontal disease in pregnancy-II correlation between oral hygiene and PD condition. Acta Odontal Scand. 1964; 22: 121-135.

11- Löe H, Silness J. Periodontal disease in pregnancy-I prevalence and severity. Acta Odontal Scand. 1963; 21: 533-551.

12- Chen M, Anderson R, Barms M. Comparing Oral Health Care System. A Second International Collaboration Study. World Health Organization Geneva, Switzerland; 1997.

13- Honkala E, Freeman R. Oral hygiene behavior and periodontal status in European adolescents. Community Dent Oral Epidemiol. 1988; 16 (4): 194-198.

14- Honkala E, Kannas L, Rise J. Oral health habits of school children in 11 European Countries. Int Dent J. 1990; 40 (4):
211-217.

15- Peterson PF: Oral health behavior of 6 year old Denish children. Acta Oodontal Scand. 1992; 50: 57-64.

16- Freeman R, Maizels, Wyllic M, Sheiham A. The relationship between health related knowledge, attitudes and dental hea1th behaviors in 14-16 years old adolescents. Community Dent Health. 1993; 10: 397-404.

17- Al-Alousi W, Al-Sayyab M. Plaque, gingival condition and brushing behaveour in 15 years old Iraqi school children in the central region of Iraq. Iraqi Dent J. 1996; 18: 127-136.

18- Al-Azawi L. Dental knowledge behaveior and attitude among children in $\mathrm{Al}-$ Buetha village, Baghdad, $J$ Coll Dent. 2001; 9: 131-135.

19- Khamrco TY, Makani LA. Dental health status in Al-Sada and Bahwiza village, Ninevah City. Iraqi Dent J. 1997; 20: 323.

20- Al- Ani RS. Dental health care delivery for 12-15 years old school children in Ramadi City, Iraq. MSc Thesis, University of Baghdad 1998.

21- Al- Ajrab M Gh. oral hygiene and gingival health status among teenagers population lived in Al-Rashidiya, Ninevah. Al-Rafidain Dent J. 2005; 5 (2): 121126.

22- Makani LA. Oral hygiene and gingival health among adolescents and adult population (15-44) years in Sharkhan village. Al-Rafidain Dent J. 2001; 1(1): 117.

23- Salman FD. Assessment of oral cleanliness and gingival condition among intermediate Thamarian school students. AlRafidain Dent J. 2006; 6(2): 181-185.

24- Khamrco TY, Al - Mashhadani BA, Al -AJrab MGh. Plaque, gingival condition and brushing behaviour among school children aged 11 - 12 years in Qadha, Singar, Ninevah/ Iraq. Al-Rafidain Dent J. 2002; 2(2): 184 - 191.

25- Honkala E, Rimpela M, Pasanen M. Trends in the development of oral hygiene habits in Finnish adolescents from 1977-1981. Community Dent Oral Epidemiol. 1984; 12(2): 72-77.

26- Ambjornsen E. Remaining teeth, periodontal conditions, oral hygiene and tooth cleaning habits in dentate old age subj- 
ects. J Clin Periodontol. 1986; 13 (6): 583-589.

27- Griffiths G. Periodontal disease and malocclusion in 11 to 12 years old school children in South Wales, MSc Thesis, University of Wales 1989.

28- Athanassouli T, Kolesti KH, Mami H, Panagopulos H. Oral health status of adult population in Athens, Greece. Community Dent Oral Epidemiol. 1990; 18 (2): 82-84.

29- Nowjack R, Ainoma J, Suomi J, Kingman A, Driscollow L, Brown L. Improved periodontal status through self assessment A 2 year longitudinal study in teenagers. J Clin Periodontol. 1995; 22(8): 603-608.

الشيخ عبدال, عبد الخـالق قاسـم, خمركو, طـارق يوسف. حالة الفم والأسنان في قريخة شريخان , مجلة

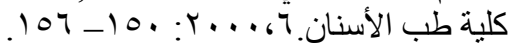

31- Makani LA. Evaluation of trials of dental health education in improving gingival health MSc Thesis, College of Dentistry, University of Mosul, 1998.

32- Al-Dahan AA, Muhi-Aldeen LK. Gingival health status among children and teenagers in Fingan village, Baghdad. Iraqi Dent J. 1998; 23: 97-107.

33- Rahimah AK. Profile of periodontal condition in elected West Malaysian adults.
Singapore Dent J. 1994; 19: 4-7.

34- Oliver Rc, Brown LJ, Le H. Periodontal disease in the United States population. J Periodonol. 1998; 69(2): 269-278.

35- Peterson PE, Razanamihaja N. Oral hea1th status in children and adult in Madagascar. Int Dent J. 1996; 46: 41-47.

36- Al-Sayyab M., Al-Alousi W, Al-Dujaili D. Periodontal treatment needs among 15 years old Iraqi school children in the city of Baghdad. Accepted in J Coll Dent. 1991.

37- Al-Beriuti N, Toyfour MT, Poulos W. Oral health status of students in Syrian Arab Republic. East Meditter Health J. 1996; 304-310.

38- Sicilia A, Cabo J, Sanz M. Periodontal treatment needs in the young population in Ovideo, Spain. Community Dent Oral Epidemiol. 1990; 18: 223-224.

39- Kalliop Murtammaa H. Determinant of self assessed gingival health among adolescents. Acta Odontal Scand. 1997; 55: $106-110$.

40- Baelum V, Manji F, Fejerkov O, Wanzala P. Validity of CPITNS assumption of hierachical occurrence of periodontal condition in a Kenyan population aged 15-65 years. Community Dent Oral Epidemiol. 1993; 21: 347-353. 